\title{
Hysteroscopic findings in patients with post-menstrual spotting with prior cesarean section
}

\author{
Achados histeroscópicos em pacientes com sangramento pós-menstrual \\ tipo escape com cesárea anterior
}

\author{
Valdely Helena Talamonte ${ }^{1}$, Umberto Gazi Lippi ${ }^{2}$, Reginaldo Guedes Coelho Lopes ${ }^{2}$, Sueli Aparecida Batista Stabile
}

\begin{abstract}
Objective: To identify uterine hysteroscopic findings among patients with prior cesarean section and whom had post-menstrual bleeding spotting type. Methods: We conducted a descriptive and prospective study between June 2008 and December 2009 involving women admitted to our clinic in Ji-Paraná (RO), Brazil, and who complained of prolonged genital bleeding after menstrual period. A total of 20 women with the simultaneous following characteristics were selected: at least one prior cesarean section, aged between 18 and 45 years, no use of hormonal contraceptives, and no history of uterine surgery that could change the cavity anatomy. All participants underwent a hysteroscopic examination. Results: During hysteroscopy, in $90 \%$ of the patients, the presence of a cesarean section scar was observed in the last third of the cervix. This scarring causes an anomaly in the uterine cavity anatomy, characterized by the viewing of an enlargement followed by a retraction of the anterior wall, which affords the presence of a pseudocavity with depth and lumen narrowing in variable degrees. Two patients did not present the pseudocavity. Conclusion: Pseudocavities in cesarean section scar are usually found in hysteroscopic examination of patients with prior cesarean section and abnormal uterine spotting.
\end{abstract}

Keywords: Uterine hemorrhage; Cesarean section; Cicatrix; Hysteroscopy

\section{RESUMO}

Objetivo: Identificar os achados histeroscópicos uterino em grupo de pacientes com operação cesariana anterior e sangramento pós-menstrual tipo escape. Métodos: Foi realizado um estudo descritivo e prospectivo, com mulheres que compareceram em consultório em Ji-Paraná (RO), entre junho de 2008 e dezembro de 2009, com queixa de sangramento genital prolongado tipo escape após período menstrual. Destas, foram selecionadas 20 mulheres que apresentavam, simultaneamente, as seguintes características: ao menos uma cesárea prévia; idade entre 18 e 45 anos; sem uso de método anticoncepcional hormonal; e ausência de qualquer outra cirurgia uterina capaz de alterar a anatomia da cavidade. As pacientes selecionadas foram submetidas a exame histeroscópico. Resultados: À histeroscopia, em $90 \%$ das pacientes, observou-se, no terço final do colo, a presença da cicatriz de cesárea. Essa cicatriz causa, no interior da cavidade uterina, uma anomalia em sua anatomia, caracterizada pela visualização, na parede anterior, de uma dilatação seguida de retração, que proporciona a presença de pseudocavidade com profundidade e oclusão da luz em graus variáveis. Já em duas pacientes, não foi detectada a pseudocavidade. Conclusão: A pseudocavidade na cicatriz da cesariana é o achado mais frequente à observação histeroscópica em pacientes com cesárea prévia e sangramento uterino anormal pós-menstrual tipo escape.

Descritores: Hemorragia uterina; Cesárea; Cicatriz; Histeroscopia

\section{INTRODUCTION}

In the middle of the 20th century there was a rising of cesarean section rates worldwide. In Brazil, these rates are higher in the South and Southeast (40.3 and 42.1\%, respectively) than in Central-western (35.9\%), North $(27 \%)$ and Northeast $(25.9 \%)$ regions ${ }^{(1)}$.

This rise was due to several reasons. In the past, most of interventions were done because of mechanical dystocia, cephalopelvic disproportion and abnormal presentation. As the procedure became safer and under the excuse to reduce newborn morbidity and mortality there was an increase in number of these procedures. Other indications became common, such as prior

Study carried out at clinic and Hospital Cândido Rondon - Ji-Paraná (RO), Brazil.

${ }^{1}$ Instituto de Assistência Médica ao Servidor Público Estadual - IAMSPE, São Paulo (SP), Brazil.

${ }^{2}$ Obstetric and Gynecology Service, Hospital do Servidor Público Estadual "Francisco Morato de Oliveira" - FMO, São Paulo (SP), Brazil.

${ }^{3}$ Hospital Cândido Rondon - Ji-Paraná, Rondônia (RO), Brazil.

Corresponding author: Valdely Helena Talamonte - Rua Mato Grosso, 1.642 - Casa Preta-Zip code: 76907-562 - Ji-Paraná (RO), Brazil - Phone.: (69) 3416-9380 - E-mail: ricardovaldely@hotmail.com

Received on: Apr 26, 2011 - Accepted on: Dec 13, 2012

Conflict of interests: None 
cesarean section, nonreactive fetus to cardiotocography at rest, pelvic presentation, pregnant women with HIV and for sterilization procedures, particularly before this subject was regulated by law. Because of the increase of primary cesarean sections in young women, the repetition of this surgery also increased, representing today 15 to $45 \%$ of all births ${ }^{(2)}$.

Abnormal uterine bleeding (AUB) is the most common complaint in gynecology offices. Freitas et al. ${ }^{(3)}$ pointed out that $50 \%$ of women aged about 45 years and $20 \%$ of teenagers have this complaint. The same authors defined dysfunctional uterine bleeding as a blood loss from the uterine cavity originated from the endometrium in the absence of anatomical changes, which may be attributed to changes in neuroendocrine mechanism that control menstruation. Therefore, this is a diagnosis of exclusion that should be only made when other causes are excluded. It is often associated to an abnormal ovarian function and anovulation, but may also occur in ovulatory cycles. Coagulopathies, endometrial atrophy and threatened abortion should be considered in the differential diagnosis.

There are some reports of patients with AUB who had undergone prior cesarean sections, specially postmenstrual spotting which may to be attributed to scar defects left in uterus by the surgery, forming a diverculum, an anomaly called by some authors as "isthmocele", and that Morris ${ }^{(4)}$ named "cesarean scar syndrome".

Despite the scarcity of studies on this subject, Fabres et al. ${ }^{(5)}$ stated that post-menstrual bleeding may be explained either by the mechanical obstruction caused by the thickness of the superior edge of cesarean section scar, or due to the accumulation of blood in the diverticulum. However, Thurmond et al. ${ }^{(6)}$ suggested that its occurrence is due to a retraction of the scar tissue causing a dilation of the lumen or a pseudocavity in the lower segment, which is limited in the upper portion by the endometrium and myometrium thickening, blocking the area in several degrees. According to these authors, the causes of such changes are unknown, but may be attributed to differences in the healing process of each side of the incision.

A study including 51 uterus of women submitted to hysterectomy and who had post-menstrual bleeding, pelvic pain, history of prior cesarean section, and were refractory to any treatment was done by Morris ${ }^{(4)}$. In this study he found several anomalies related to the scar, such as: distortion and enlargement of lower segment, congested endometrium above the scar, lymphocyte infiltration and capillary dilation. These conditions might interfere with the drainage of menstrual blood justifying its intermittent discharge, and so affecting fertility. This could last until ovulation when the estrogen peak occurs and leads to relaxation of internal orifice of the cervix ${ }^{(7)}$.

A total of 43 women who had at least one prior cesarean were assessed by Borges et al. ${ }^{(8)}$ by hysteroscopy (HSC) who come to the conclusion that 38 of the participants $(88.17 \%)$ had isthmocele.

According to Lasmar et al. ${ }^{(9)}$, the diagnosis of the changes in cesarean section scars could be performed by ultrasonography, hysterosalpingography and HSC. Nowadays HSC is considered the most appropriated method to diagnose cesarean section scar and it also enables surgical treatment. Hysteroscopic alterations seem to be related to histopathological aspects.

\section{OBJECTIVE}

To identify hysteroscopic findings in a group of patients who had undergone prior cesarean section and had post-menstrual bleeding spotting type.

\section{METHODS}

This is a prospective, descriptive study at a private clinic in city of Ji-Paraná (RO) from July 2008 to December 2009 with women who complained of prolonged genital spotting after the menstrual period.

From patients who complained of prolonged genital spotting we selected 20 women who had simultaneously the following characteristics: at least one prior cesarean section; age between 18 and 45 years; no use of hormonal contraceptives, and no history of uterine surgery that could change the cavity anatomy.

We submitted the participants to hysteroscopy examination at the Hospital Candido Rondon using hysteroscopy of $2.9 \mathrm{~mm}$ (HOPKINS II Forward-Oblique

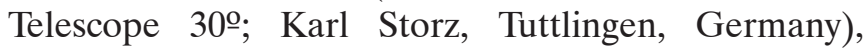
without anesthesia or analgesia. Saline solution was used as a distension manner under pressure of 50 to $80 \mathrm{mmHg}$. All tests were performed in the proliferative period of the menstrual period. All participants read and signed the informed consent form.

This research was approved by the Ethical and Research Committee of Hospital Candido Rondon and also by the Ethical and Research Committee of Instituto de Assistência Médica ao Servidor Público Estadual (IAMSPE), and was registered under the number 062/09.

\section{RESULTS}

The mean interval elapsed between AUB appearance and the cesarean section was 6 months. Length of 
bleeding time varied from four days after menstruation cessation until the whole menstrual interval with a mean of eight days. The patients' age varied from 18 to 43 years, with a mean age of 36 years. Parity varied from 1 to 4 cesarean sections, with a mean of 2.3. Two patients reported problems to get pregnant for a second time. The uterine size varied from 48.6 to $365 \mathrm{~cm} 3$ (mean of 206).

We observed a cesarean section scar using the HSC in 18 patients $(90 \%)$ in the last third of the cervix. This scarring in the uterine cavity causes an anomaly in its anatomy characterized by the viewing of an enlargement followed by a retraction on the anterior wall, which affords the presence of a pseudocavity with depth and lumen narrowing in variable degrees (Figure 1). Two patients did not show pseudocavity.

We observed in four of those women who had cesarean section scar, a discharge of dark brown blood inside the pseudocavity during the examination. Another four women besides that blood discharge presented endometrial polyps. A pseudocavity and submucous myoma was seen in three patients, and two presented granuloma inside the pseudocavity, the five remaining participants did not have any bleeding or endometrial disease.

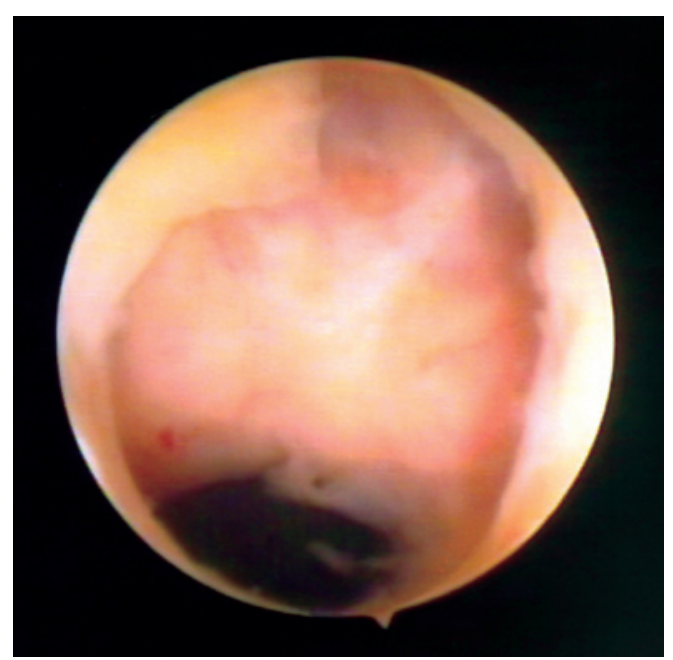

Figure 1. Hysteroscopy imaging of cesarean section scar and seudodiverticulum formation

\section{DISCUSSION}

After the exclusion of systemic organic affections or hormonal imbalances as the causes of AUB postmenstrual spooting, it becomes mandatory the screening for hysterotomy scar imperfections if the woman had undergone one or more cesarean sections. Morris ${ }^{(4)}$ suggested the name caesarean scar syndrome for this anomaly. In this study we also identified this anomaly, because $90 \%$ of the evaluated patients had retraction in the cesarean section scar.

Many authors refer defects on postoperative scar as the cause of post-menstrual spotting. Van Horenbeek et al. ${ }^{(10)}$ observed divercula formation in scars, at ultrasonography and HSC. after analyzing patients with secondary infertility. They reported that repairing the abnormality stoped the abnormal bleeding as well as it enabled a spontaneous pregnancy, however, it ended in abortion.

Another study by Erickson and Vooris ${ }^{(11)}$ evaluated three patients who had complained of AUB. They observed by transvaginal ultrasonography that the patients showed diverticulum formation at the cesarean section scar and that inside that sac there was a heterogeneous material that resembled blood. Another research carried out by Armstrong et al. ${ }^{(12)}$ also detected after transvaginal ultrasonography a fluid within a post cesarean section scar defect in $56 \%$ of patients.

The diverticulum formation or sac as a defect in the cesarean section scar according to Thurmond et al. ${ }^{(6)}$ might be due to the lack of coordinated muscular contractions in the uterine tissue close to the scar, and at this site occurs an accumulation of menstrual blood that is slowly released during few days after a regular menstrual flow.

A study by Fabres et al. ${ }^{(5)}$ evaluated 92 women submitted to cesarean section and who had history of AUB. All patients in that study underwent transvaginal ultrasonography and HSC. The authors found, in both exams, a sac in the anterior segment of the uterus in the cesarean section scar. A wide correlation between AUB and the anatomic defect was found, and they also verified that the larger the sac was the heavier and longer was the bleeding.

Another complication could be the sac formation by cesarean section scar, and ectopic pregnancy at the site $^{(13,14)}$

Some questions need to be answered such as: do all cesarean section scars lead to a diverticulum? Why some patients present the diverticulum with AUB and other do not? Does the suture and thread type interfere on the diverticulum formation? Even as speculation it is possible to suppose that scars which result from a continuous anchoring suture might disrupt the circulation of the tissue, leading to necrosis and diverticulum formation much more than those tissues treated with a simple suture. This is an important issue for future research, because if this hypothesis is confirmed a massive change in the method applied for myometrial suture will be made, so suture with separate 
stitches will be preferred instead of an anchoring suture that should be abolished.

\section{CONCLUSION}

This study has concluded that pseudocavity in cesarean section scar is often found at hysteroscopy in patients who had prior cesarean section and AUB post-mestrual spotting.

\section{REFERENCES}

1. Taxas de parto normal e cesárea no Brasil; situação atual 1995-2003. J FEBRASGO. 2004:11(3):4-6

2. Costa SH, Ramos JG, Reis R. Operação cesariana. In: Freitas F, Martins Costa SH, Ramos JG, Magalhães JA. Rotinas em obstetrícia. 5a ed. Porto Alegre: Artmed; 2006. p. 181-98.

3. Freitas F, Cunha-Filho SL, Glitz CL, Valiati B, Wender MC. Sangramento uterino anormal. In: Freitas F, Menke CH, Rivoire W, Passos EP, organizadores. Rotinas em ginecologia. 5a ed. Porto Alegre: Artmed; 2006. p.102-12.

4. Morris H. Surgical pathology of the lower segment cesarean section scar: is the scar a source of clinical symptoms? Int J Gynecol Pathol. 1995; 14(1):16-20.
5. Fabres C, Aviles G, De La Jara C, Escalona J, Muñoz JF, Mackenna A, et al. The cesarean delivery scar pouch: clinical implications an diagnostic correlation between transvaginal sonography and hysteroscopy. J Ultrasound Med. 2003;22(7):695-700.

6. Thurmond AS, Harvey WJ, Smith AS. Cesarean section scar as a cause of abnormal vaginal bleeding: diagnosis by sonohyterography. J Ultrasound Med. 1999;18(1):13-6.

7. Scapinelli A, Lugó C, Depes DB, Yatabe S, Gomes AM, Baracat F, et al Cicatriz da cesariana: implicações ginecológicas e aspectos atuais. Femina. 2009;37(7):395-8.

8. Borges M, Scapinelli A, Depes PB, Lippi UG, Lopes RG. Findings in patients with postmenstrual spotting with prior cesarean section. J Minim Inv Gynecol. 2010:17(3):361-4.

9. Lasmar RB, Rosa DB, Parente RC, Lunardi CS, Silveira LP, Fabricio MI. Aspectos histeroscópicos da cicatriz de cesariana. In: Crispi C, Malche F, Damoian JC, Oliveira MA. Tratado de videoendoscopia e cirurgia minimamente invasiva em ginecologia. Rio de Janeiro: Revinter; 2007. p. 960-7.

10. Van Horenbeek A, Temmerman M, Dhont M. Cesarean scar dehiscence and irregular uterine bleeding. Obest Gynecol. 2003;102(5 Pt 2):1137-9.

11. Erickson SS, Van Voorhis BJ. Intermentrual bleeding secondary to cesarean scar diverticuli: report of three cases. Obstet Gynecol. 1999;93(5 Pt2):802-4.

12. Armstrong V, Hansen WF, Van Voorhis BJ, Syrop H. Detection of cesarean scars by transvaginal ultrasound. Obstet Gynecol. 2003;101(1):61-5.

13. Shufaro $Y$, Nadjari M. Implanation of as a gestacional sac in a cesarean section scar. Fertil Steril. 2001;75(6):1217.

14. Rojas-Cardenas JC, Duarte PC. Embarazo ectópico em cicatriz de cesárea: reporte de caso. Rev Colomb Obstet Ginecol. 2007;58(1):65-9. 